\title{
АНАЛІЗ ГІДРОГЕОЛОГІЧНИХ І ГЕОТЕРМІЧНИХ ХАРАКТЕРИСТИК ГЕОТЕРМАЛЬНИХ ОБ'ЄКТІВ УКРАЇНИ
}

\author{
А.А. Барило \\ Інститут відновлюваної енергетики НАН України, \\ 02094, вул. Гната Хоткевича 20А, м. Київ, Україна.
}

На основі матеріалів «Держсавного інформаційного геологічного фонду України» створено базу даних геотермальних об'єктів, в яку увійшло 655 об 'єкта, які охоплюють 12 адміністративних областей Украйни і близько 54 \% існуючих родовищ вуглеводнів. Основними геотермічними і гідрогеологічними характеристиками об'єктів бази даних є: глибина залягання, літологія і склад порід, геологічний вік порід, товщина продуктивного горизонту, пластова температура $і$ пластовий тиск, дебіт свердловини, зниження рівня води у водоносному горизонті під час випробування, мінералізація, газовий склад $i$ вміст природного газу у підземних водах.

Аналіз гідрогеологічних $і$ геотермічних характеристик геотермальних об'єктів виконано на основі структурногідрогеологічного принципу, тобто усі об'єкти розглядались стосовно крупних гідрогеологічних структур з єдиними регіональними межами і умовами формування родовищ підземних вод. Було проаналізовано чотири гідрогеологічні структури: Закарпатський внутрішній прогин, Прикарпатський передгірний прогини, Дніпровсько-Донецький артезіанський басейн та Причорноморський артезіанський басейн. Для кожної структури побудовано діаграми розподілу пластових температур, глибин залягання і мінералізації підземних вод в геотермальних об'єктах бази даних.

Аналіз показав, щчо умови формування геотермальних родовищ в першу чергу залежать від теплового фону земних надр, але на прочеси формування родовищ дуже істотний вплив має глибина залягання кристалічного фундаменту, розташування областей живлення і розвантаження термоводоносних горизонтів, глибина сучасного водообміну, літологічний склад водовмісних порід.

Створена база даних геотермальних об'єктів України може бути використана під час вибору першочергових проектів освоєння геотермальних ресурсів, а також для стратегічного планування геотермальної галузі в цілому. Бібл. 10, рис. 14.

Ключові слова: геотермальний об’єкт, електрона база даних, геотермічна характеристика, гідрогеологічна характеристика, діаграма розподілу.

\section{ANALYSIS OF HYDROGEOLOGICAL AND GEOTHERMIC CHARACTERISTICS OF THE GEOTHERMAL OBJECTS OF UKRAINE}

\author{
A. Barylo \\ Institute of Renewable Energy of the National Academy of Sciences of Ukraine, \\ 02094, 20A Hnata Khotkevycha St., Kyiv, Ukraine.
}

On the basis of the materials of the State Geological Information Fund of Ukraine, a database of geothermal objects was created, which included 655 objects, covering 12 administrative regions of Ukraine and about 54\% of the existing hydrocarbons. The main geothermal and hydrogeological characteristics of the database objects are: depth of productive horizon, lithology and composition of rocks, geological age of rocks, thickness of productive horizon, aquifer temperature and reservoir pressure, well flow, water level drop in aquifer during testing, mineralization, gas composition and natural gas content in groundwater.

The analysis of hydrogeological and geothermal characteristics of geothermal objects was performed on the basis of the structuralhydrogeological principle. That is, all objects were considered in relation to large hydrogeological structures with unified boundaries and conditions of groundwater deposits formation, such as: Transcarpathian Bend, Procarpathian Bend, Dneprovsko-Donetsk artesian basin and Black Sea artesian basin. For each structure, diagrams of the distribution of formation temperatures, depths of deposition and mineralization of groundwater in geothermal objects of the database are constructed.

The analysis showed that the conditions of the geothermal deposits generation primarily depend on the thermal subsoil background. But very significant influence have the crystalline basement depth, the location of areas of supply and unloading of geothermal horizons, the depth of modern water exchange, lithologic composition of water containing rocks.

The database of geothermal objects of Ukraine can be used during the selection of priority geothermal projects for the development, as well as for strategic planning of the geothermal industry as a whole. Ref. 10, fig. 14.

Keywords: geothermal object, electronic database, geothermal characteristics, hydrogeological characteristics, distribution diagram. 


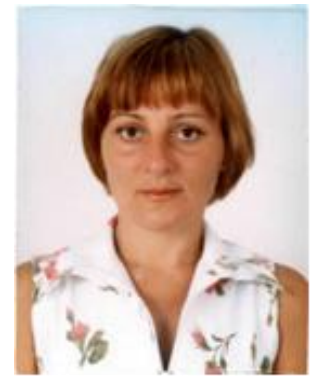

A.A. Барило A. Barylo
Відомості про автора: науковий співробітник відділу геотермальної енергетики Інституту відновлюваної енергетики НАН України. Освіта: Київський Державний університет, факультет гідрогеології та інженерної геології. Наукова сфера: відновлювана енергетика, геотермальна енергетика, використання тепла довкілля.

Публікації: 58.

ORCID: 0000-0001-7981-6464

Контакти: тел./факс: +38 (044) 206-28-09

e-mail: geotherm@ukr.net
Author information: researcher at Geothermal Energy Department, Institute of Renewable Energy of National Academy of Sciences of Ukraine.

Education: Kyiv National University, Faculty of Hydrology and Engineering Geology.

Research area: renewable energy, geothermal energy, use of environmental heat. Publications: 58.

ORCID: 0000-0001-7981-6464

Contacts: phone/fax: +38 (044) 206-28-09

e-mail: geotherm@ukr.net
Вступ. В ході проведення пошуковорозвідувальних робіт на нафту, природний газ i конденсат виконуються гідрогеологічні дослідження, які виявляють глибинні водоносні горизонти, що містять термальну воду. Ці відомості дають попередню інформацію про можливість формування геотермальних родовищ та мають принципове значення на початковому етапі розвитку геотермальних проектів. Особливо вони важливі при виборі першочергових для освоєння геотермальних об'єктів, а також для стратегічного планування геотермальної галузі в цілому.

Однак в даний час цей масив даних практично не використовується. Перш за все це пояснюється тим, що інформацією володіють геологічні організації, які не зацікавлені в розвитку геотермальної енергетики та в наданні відомостей щодо термоводоносних горизонтів України.

Проте, в останні роки в зв'язку зі збільшенням інтересу до відновлюваних джерел енергії, в тому числі геотермальних, ситуація почала змінюватися. Геологічні організації шукають нові можливості для використання вироблених і непродуктивних на вуглеводні свердловин, проводиться узагальнення геотермічної інформації, збираються дані щодо свердловин, які виявили термальні води.

Метою дослідження $є$ створення електронної бази даних геотермальних об'єктів України, аналіз гідрогеологічних і геотермічних характеристик для визначення загальних закономірностей і специфічних особливостей умов залягання та формування запасів гідротермальних родовищ.

Постановка завдання. Під гідротермальним об'єктом розуміється горизонт одновікових в геологічному відношенні порід, що містить термальні води, який був розкритий свердловиною, випробуваний, і були отримані його попередні гідрогеологічні та геотермічні характеристики. 3 вищезазначеного визначення випливає, що одна свердловина може розкрити декілька геотермальних об'єктів.

До основних гідрогеологічних і геотермічних характеристик геотермального об'єкту належать: глибина залягання, літологія і склад порід, геологічний вік порід, товщина продуктивного горизонту, пластова температура i пластовий тиск, дебіт свердловини, зниження рівня води у водоносному горизонті під час випробування, мінералізація, газовий склад і вміст природного газу у підземних водах[1-3].

На жаль на практиці під час пошуковорозвідувальних робіт в нафтових і газових свердловинах не завжди проводиться повний комплекс досліджень водоносного горизонту, тому деякі 3 необхідних характеристик можуть бути відсутні. У цьому випадку визначальним для внесення до бази даних $є$ фактичний приплив, тобто наявність термальних вод. Якщо геотермічні дослідження горизонту не проводилися, то в базу даних увійшли розрахункові характеристики, які визначалися за середнім для свердловини( або для родовища) геотермічним градієнтом. В базу даних увійшли водоносні горизонти, пластова температура яких перевищує $50^{\circ} \mathrm{C}$ [4].

База даних геотермальних об'сктів України. На основі фондових матеріалів «Державного інформаційного геологічного фонду України» [510] зібрано дані та створено електрону базу геотермальних об'єктів України. На теперішній час база даних налічує 655 геотермальних об'єкта. На діаграмі (рис. 1.) показані адміністративні області України, які представлені базою даних. Як видно 3 діаграми, інформацію зібрано по 12 областях, найбільша кількість припадає на Полтавську, Львівську, Івано-Франківську та Херсонську областях. Зауважимо, що на даний час близько 54 \% існуючих родовищ вуглеводнів увійшли до бази даних [5]. 


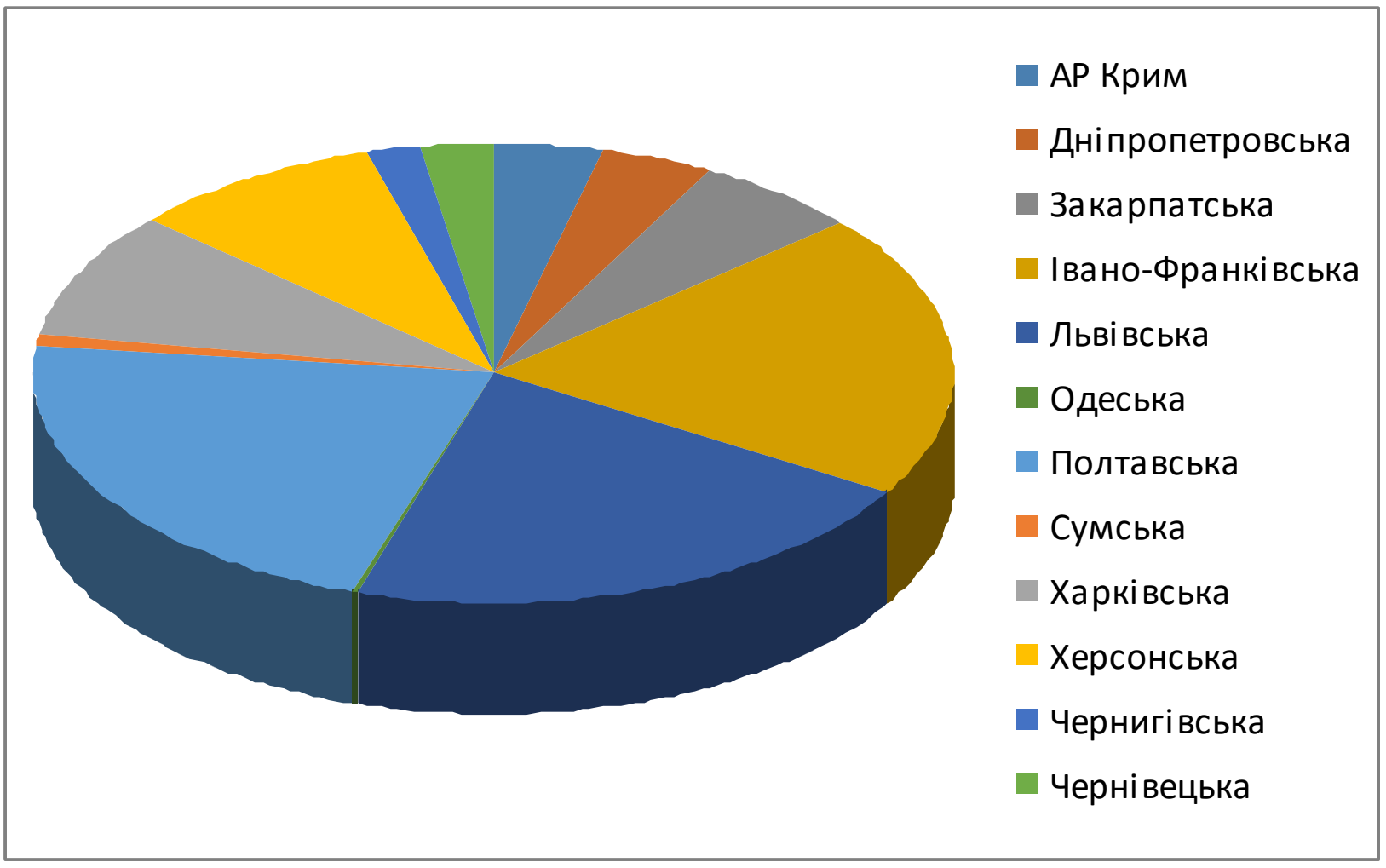

Рис. 1. Розподіл геотермальних об'єктів електроной бази даних за адміністративними областями України.

Fig. 1. Geothermal objects distribution of electronic database by administrative regions of Ukraine.

Аналіз геотермічних i гідрогеологічних характеристик. Аналіз геотермічних і гідрогеологічних характеристик об'єктів проводиться 3 метою визначення загальних закономірностей формування запасів та знаходження специфічних особливостей умов залягання геотермальних родовищ.

В основу аналізу покладено структурногідрогеологічний принцип, тобто усі геотермальні об'єкти бази даних прив'язуються до конкретних крупних гідрогеологічних структур (I-шого порядку), які представляють собою елементи підземної гідросфери, обмежені природними гідрогеологічними границями, і мають єдині умови формування підземних вод.

Усі геотермічні свердловини, які увійшли до бази даних, відносяться до наступних гідрогеологічних структур:

- Закарпатський внутрішній прогин;

- Прикарпатський передгірний прогин;

- Дніпровсько-Донецький артезіанський басейн;

- Причорноморський

артезіанський басейн.
Зібрана інформація була проаналізована для кожної гідрогеологічної структури за такими позиціями:

- глибина залягання кристалічного фундаменту,

- величина глибинного теплового потоку,

- регіональні області живлення і розвантаження геотермального горизонту,

- тип колектору,

- гідродинамічний режим продуктивного горизонту,

- глибина залягання і товщина продуктивного горизонту,

- пластова температура.

- водозбагаченість горизонту,

- $\quad$ мінералізація термальних вод.

Зауважимо, що залягання кристалічного фундаменту є важливим показником, за яким побічно можна судити про максимальні глибині залягання термоводоносних горизонтів, оскільки складається фундамент 3 щільних непроникних метаморфизованих порід, в яких дуже рідко і обмежено у просторі формуються водоносні горизонти. Крім того, породи фундаменту характери- 
зуються високою теплопровідністю (коефіцієнти теплопровідності $3,5 \mathrm{BT} / \mathrm{M}^{\circ} \mathrm{C}$ і більше), тому в його надрах тепло не накопичується.

Закарпатський внутрішній прогин. У межах структури встановлено 38 геотермальних об'єкта. Незважаючи на високий геотермічний фон даної території (величина глибинного теплового потоку Закарпатського внутрішнього прогину досягає $120 \mathrm{MBT} / \mathrm{m}^{2}$ (рис. 2.), середній геотермічний градієнт становить $5{ }^{\circ} \mathrm{C} / 100$ м. [2, 3], а для деяких родовищ він дорівнює $7-8^{\circ} \mathrm{C} / 100$ м. Переважна пластова температура геотермальних об'єктів змінюється в діапазоні від 40 до 70 (рис. 4.).

Перш за все це можна пояснити невисокою глибиною буріння свердловин. Як видно з рис. 3 , глибина залягання геотермальних об'єктів, які увійшли до бази даних, не перевищує 3 км і в середньому становить 1000-2000 м.

Крім того, формування термоводоносних горизонтів обмежує високе розташування кристалічного фундаменту. Так наприклад, абсолютні позначки фундаменту в межах Берегівського блоку складають всього 400 -1000 м [4].

Регіональною областю живлення глибоких водоносних горизонтів є зона Складчастих Карпат, по розломах і порушеннях яких холодні атмосферні води потрапляють у водоносні горизонти і охолоджують останні. Тому родовищ крупних термальних вод на території Складчастих Карпат не спостерігається.

Колектори у переважної більшості мають тріщино - поровий або тріщино - жильний тип 3 дуже нерівномірними фільтраційними властивостями як у розрізі, так і за простяганням. Водовмісні породи представлені вулканогенними утвореннями, рідше метаморфічними. Термоводоносні горизонти приурочені до зон тріщинуватості.

Як видно з рис. 5., за величиною мінералізації чітко виділяється два типи підземних вод: відносно слабко мінералізовані підземні води з мінералізацією до 50 г/л і розсоли 3 мінералізацією від 100 до 140 г/л. Походження розсолів найчастіше пов'язано з присутністю в розрізі відкладень кам'яної солі.

Продуктивні горизонти напірні, статичні рівні встановлюються на глибині до 20 м від поверхні землі. Не рідко спостерігається явище газліфта.

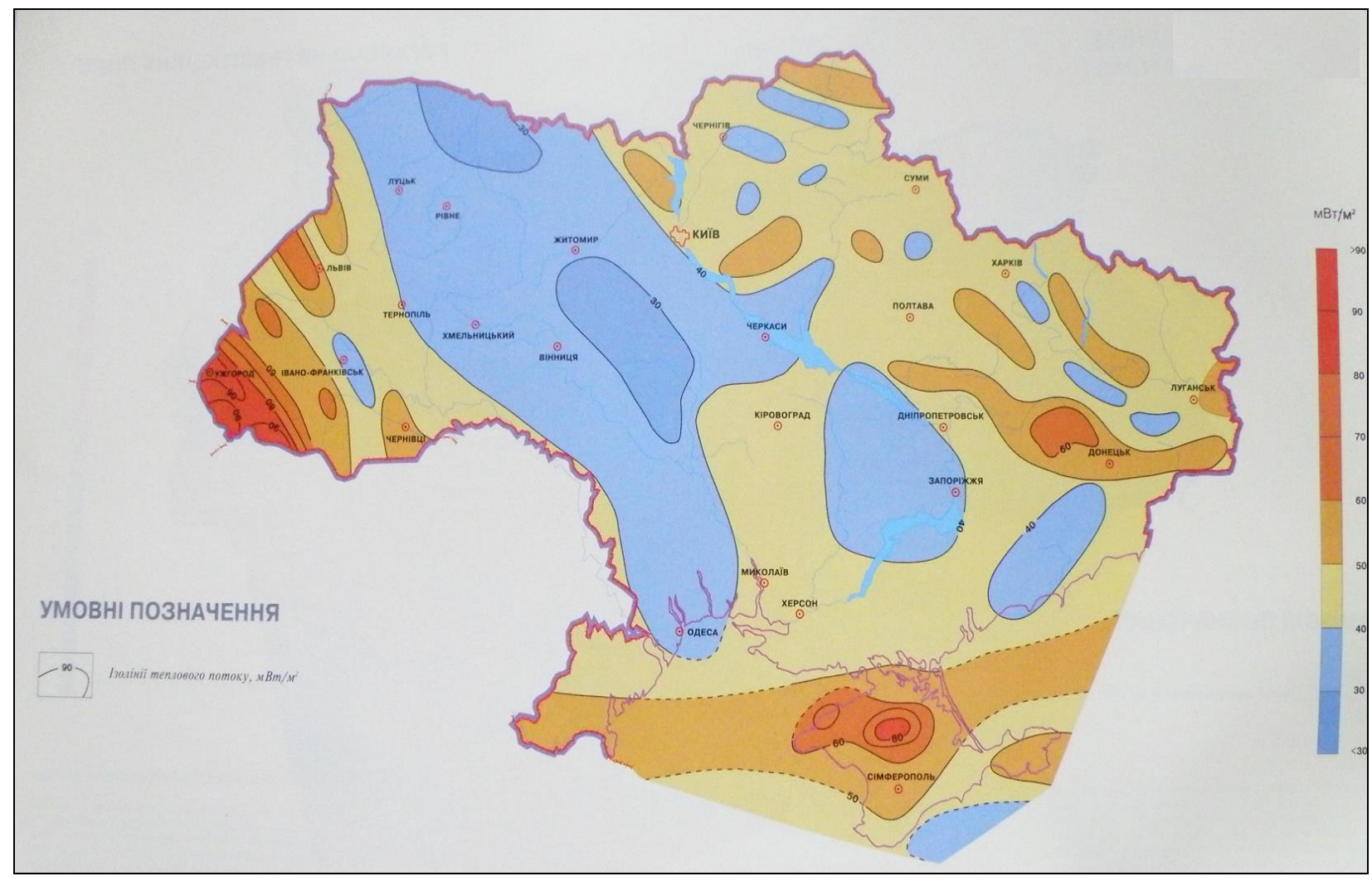

Рис. 2. Розподіл величин глибинного теплового потоку на території України, мВт/м², [6].

Fig. 2. Distribution of deep heat flux values on the territory of Ukraine, $\mathrm{mW} / \mathrm{m}^{2}$, [6]. 


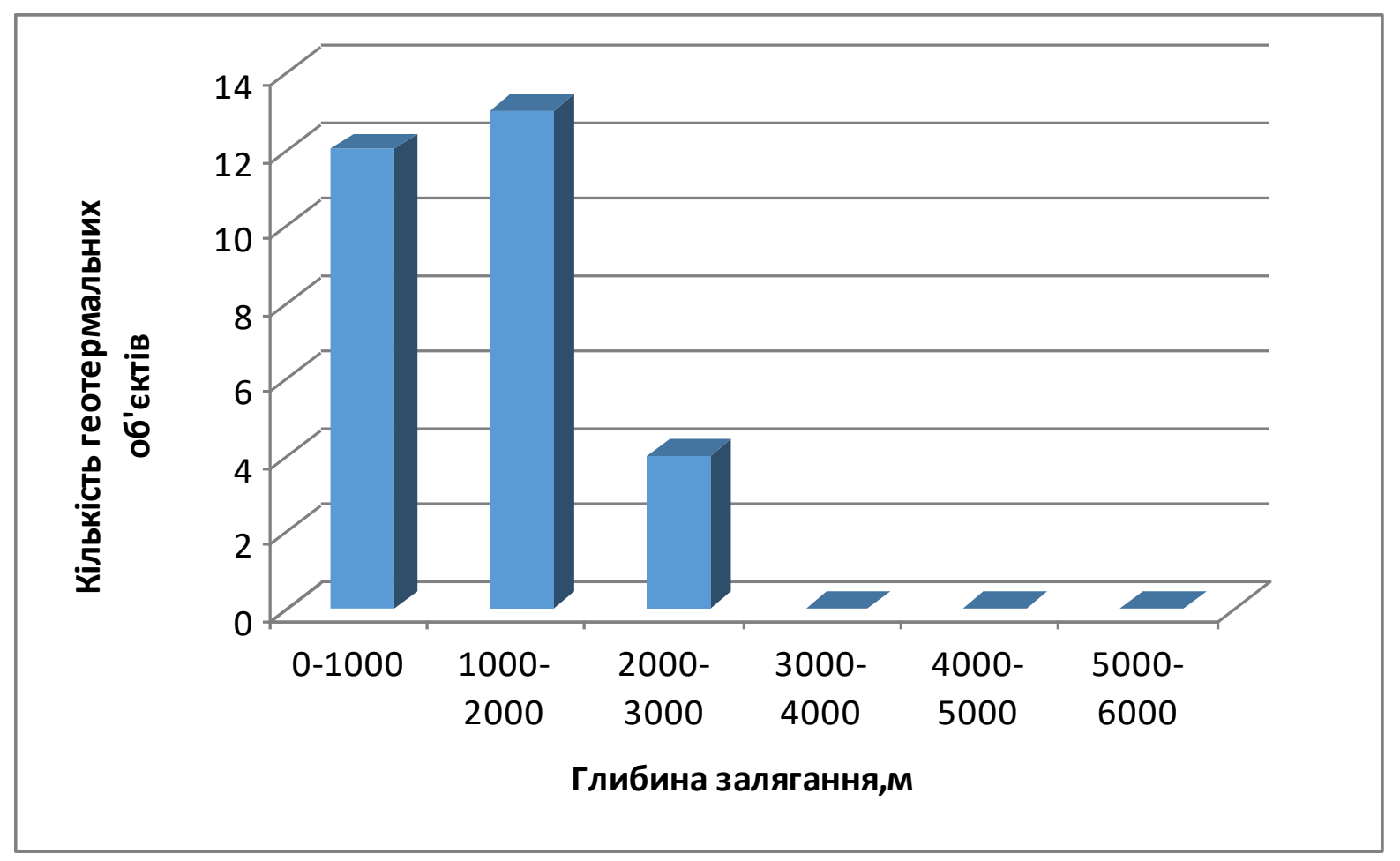

Рис. 3. Розподіл глибин залягання у геотермальних об’єктах Закарпатського внутрішнього прогину.

Fig. 3. Aquifer depth distribution in the geothermal objects of Transcarpathian region.

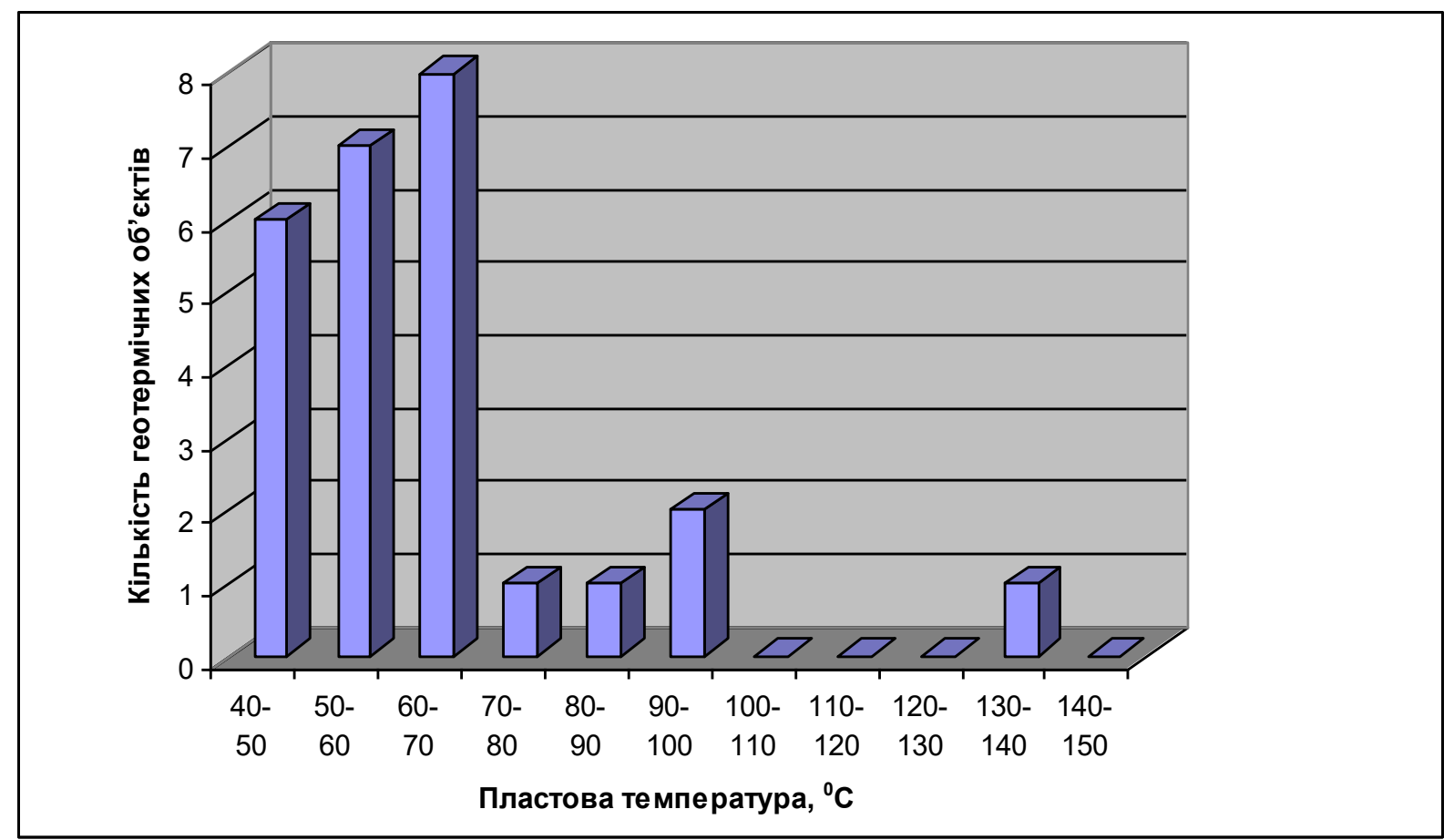

Рис. 4. Розподіл пластових температур у геотермальних об'єктах Закарпатського внутрішнього прогину.

Fig. 4. Aquifer temperature distribution in the geothermal objects of Transcarpathian region. 


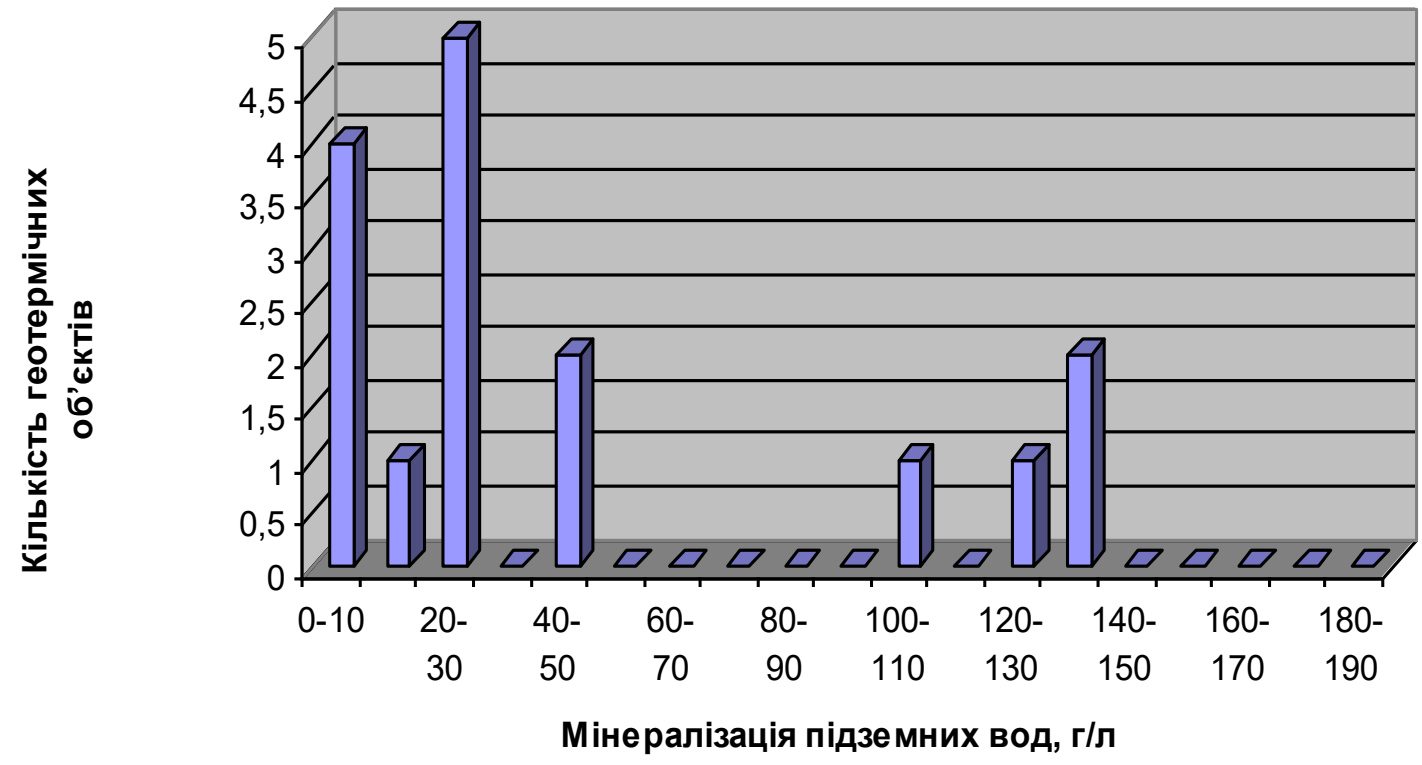

Рис. 5. Розподіл мінералізації підземних вод у геотермальних об'сктах Закарпатського внутрішнього прогину.

Fig. 4. Aquifer mineralization distribution in the geothermal objects of Transcarpathian region.

Прикарпатський передгірний прогин. На території цієї структури розташовано 129 геотермальних об'єктів Івано-Франківської області, 138 об'єктів Львівської області та 16 об'єктів Чернівецької області.

Основною областю живлення для Прикарпатського прогину за рахунок інфільтрації атмосферних опадів $\epsilon$ південно-західний схил Волино- Подільської плити, де водоносні горизонти практично виходять на денну поверхню. Далі вони занурюються в напрямку до Карпат, збільшується потужність осадової товщі. Відповідно змінюється глибина залягання фундаменту від 1 - 2 км в прибортової частині до 10 км в осьовій частині прогину.

Осадовий чохол прогину дуже структурно неоднорідний. 3 низу в гору у ньому виділяють три поверхи: докембрійсько-палеозойський, мезозойсько-палеогеновий i неогеновий. Перший представлений слабко метаморфізованими глинистими сланцями і кварцитовими пісковиками, другий - теригенними флішовими породами, а третій - піщано-глинистими утвореннями.

Тому геотермальні об'єкти, які представляють Прикарпатський прогин, дуже різноманітні.
Найбільш представлений в базі даних третій, верхній від поверхні, структурний поверх осадового чохла, з яким пов'язано більшість геотермальних об'єктів і родовищ.

Найбільш прогрітою $є$ внутрішня частина прогину, яка безпосередньо примикає до Складчастих Карпат. Середні геотермічні градієнти змінюються від 2,3- 3,5 ${ }^{\circ} \mathrm{C} / 100$ м.

Розподіл мінералізації підземних вод в об'єктах бази даних має строкатий характер. Це вказує на дуже різноманітне походження їх хімічного складу, яке залежіть насамперед від складу водовмісних порід, глибини залягання та відкритості горизонту для водного обміну. Зауважимо, що товщина соленосної формації у внутрішній зоні Прикарпатського прогину змінюється від 2250 до 6500 м. Теригенно-карбонатна формація потужністю до 2000 - 3000 м поширена в основному в зовнішній зоні прогину. Найбільша кількість об'єктів потрапила у діапазон 90-100 г/л.

Колектора також дуже різноманітні за типом, але переважно мають порово- пластовий i тріщино - пластовий тип. Горизонти напірні, статичні рівні встановлюються на глибинах від 150 м нижче до 100 м вище гирла свердловини. 


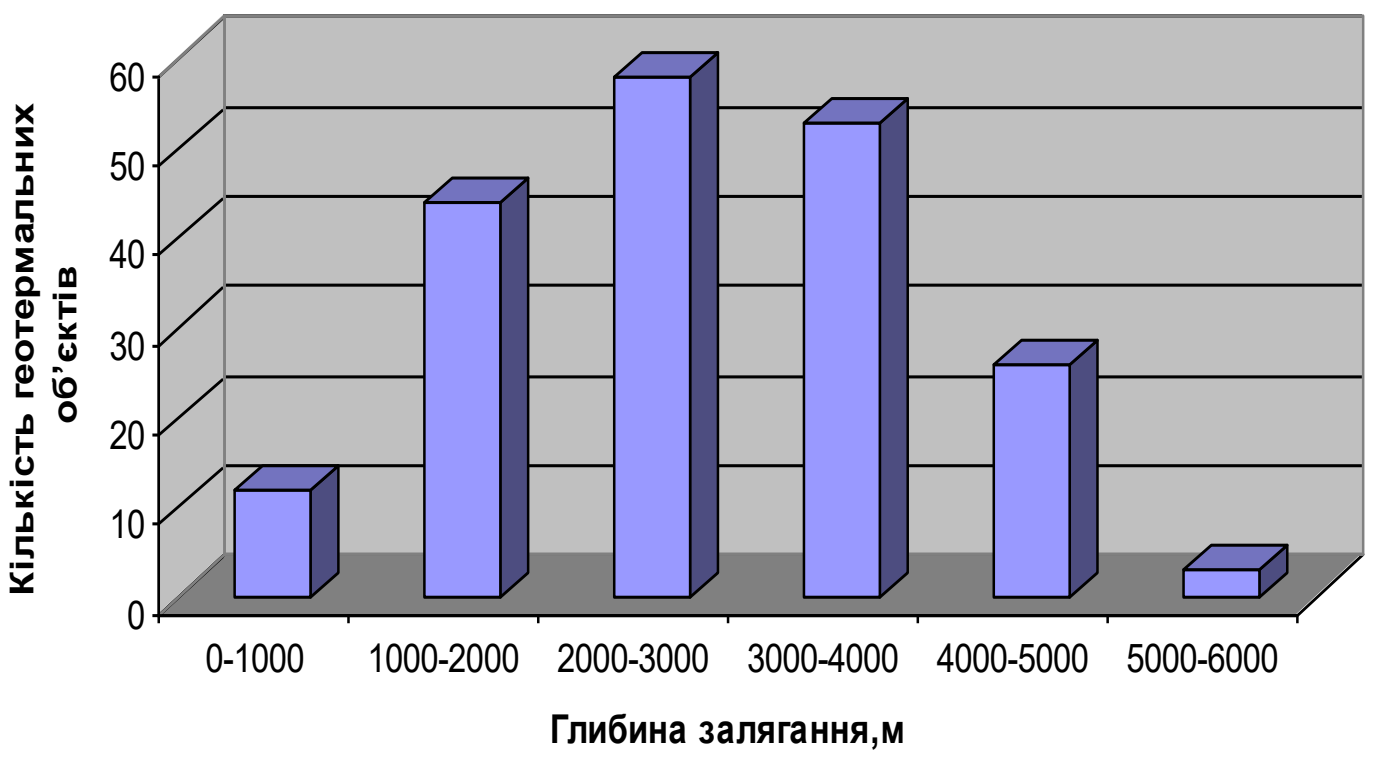

Рис. 6. Розподіл глибин залягання геотермальних об’єктів Прикарпатського прогину.

Fig. 6. Aquifer depth distributions in the geothermal objects of the Carpathian bend.

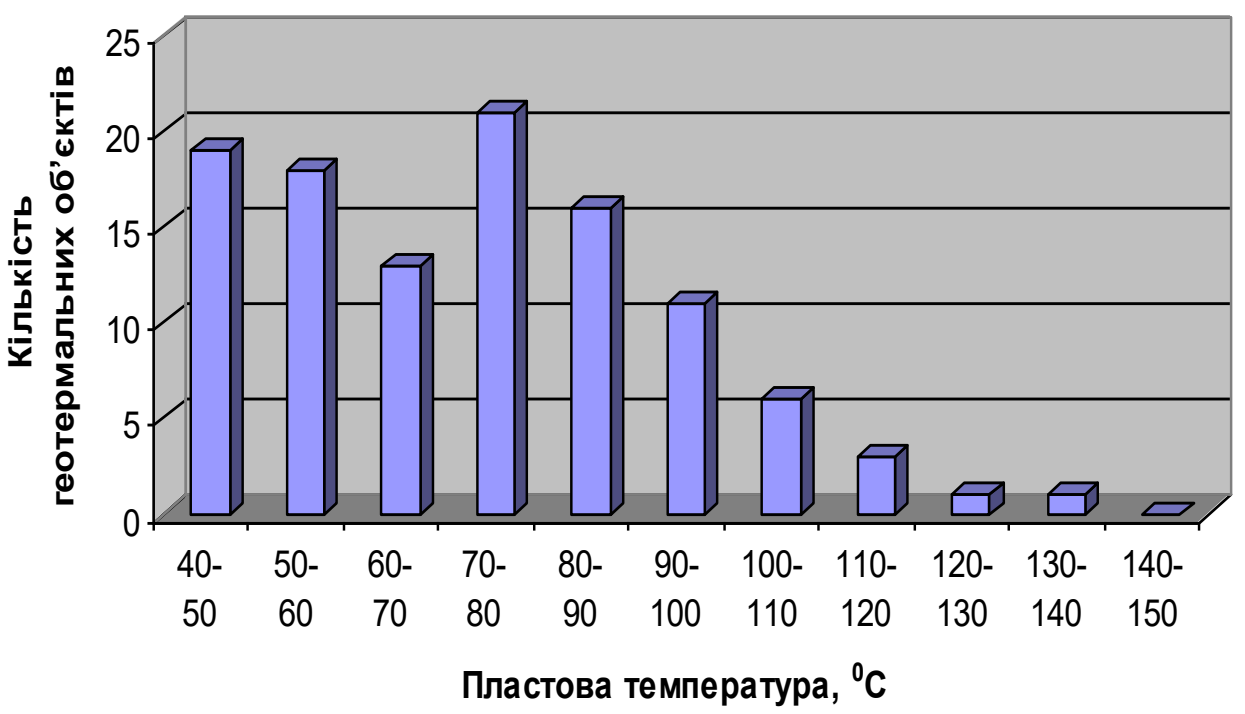

Рис. 7. Розподіл пластових температур у геотермальних об’єктах Прикарпатського прогину.

Fig. 7. Aquifer reservoir temperatures distribution in the geothermal objects of the Carpathian bend. 


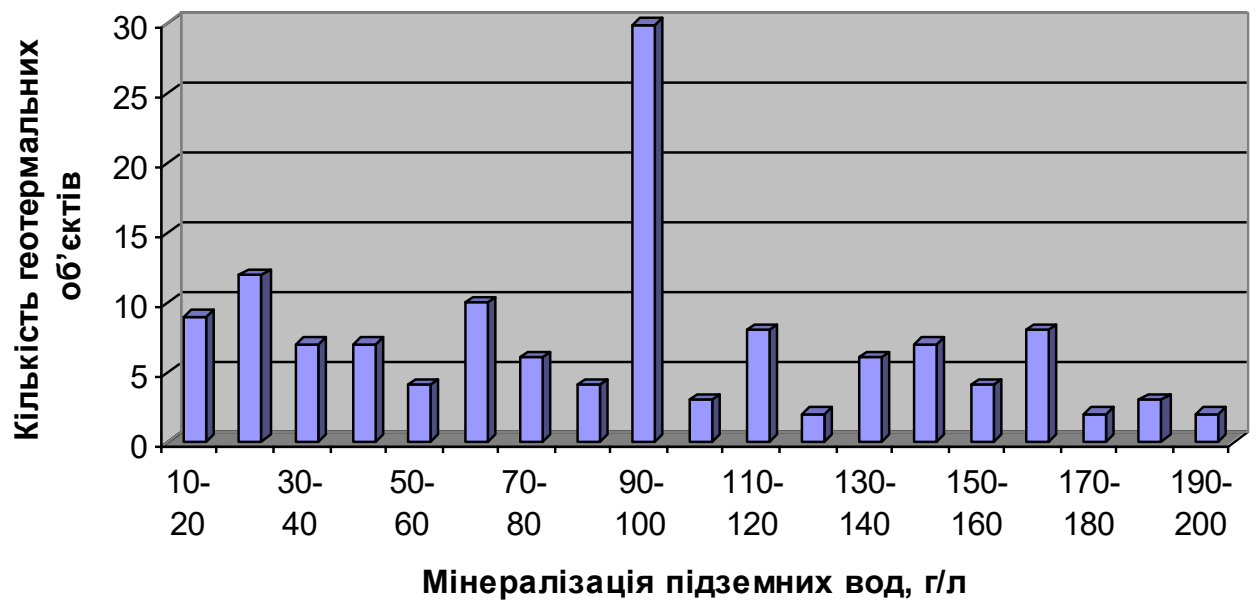

Рис. 8. Розподіл мінералізації підземних вод у геотермальних об’єктах Прикарпатського прогину.

Fig. 8. Underground mineralization distribution in the geothermal objects of the Carpathian bend.

Дніпровсько-Донецький артезіанський басейн. На території цієї структури розташовано 143 геотермальних об'єктів Полтавської області, 6 об'єктів Сумської області, 13 об'єктів Чернігівської та 58 об'єктів Харківської області.

Дніпровсько-Донецька западина $є$ складно побудований грабен, виконаний палеозойськими і мезокайнозойськими осадовими породами загальною потужністю від 2 до 12 км. Регіональної областю живлення $\epsilon$ схили щитів, 3 якими вона з'єднується $з$ околиць.

Загальний тепловий фон іiї надр невисокий (до $3{ }^{\circ} \mathrm{C} / 100$ м), однак глибоке занурювання кристалічного фундаменту і наявність потужних осадових відкладень на значній глибині з гарними фільтраційними властивостями, які чергуються 3 водотривкими глинистими горизонтами, створює в цілому сприятливі умови для формування родовищ термальних вод. Температура безпосередньо залежить від глибини залягання горизонту. Тому переважна глибина залягання геотермальних об'єктів змінюється від 1500 до 5000 м і вище, а пластова температура - від 60 до $110^{\circ} \mathrm{C}$.

У центральній частині ДніпровськоДонецької западини до глибини 5-5,5 км спостерігаються горизонти пластового типу 3 відносно високими колекторським властивостями, які мають широке поширення по площі.

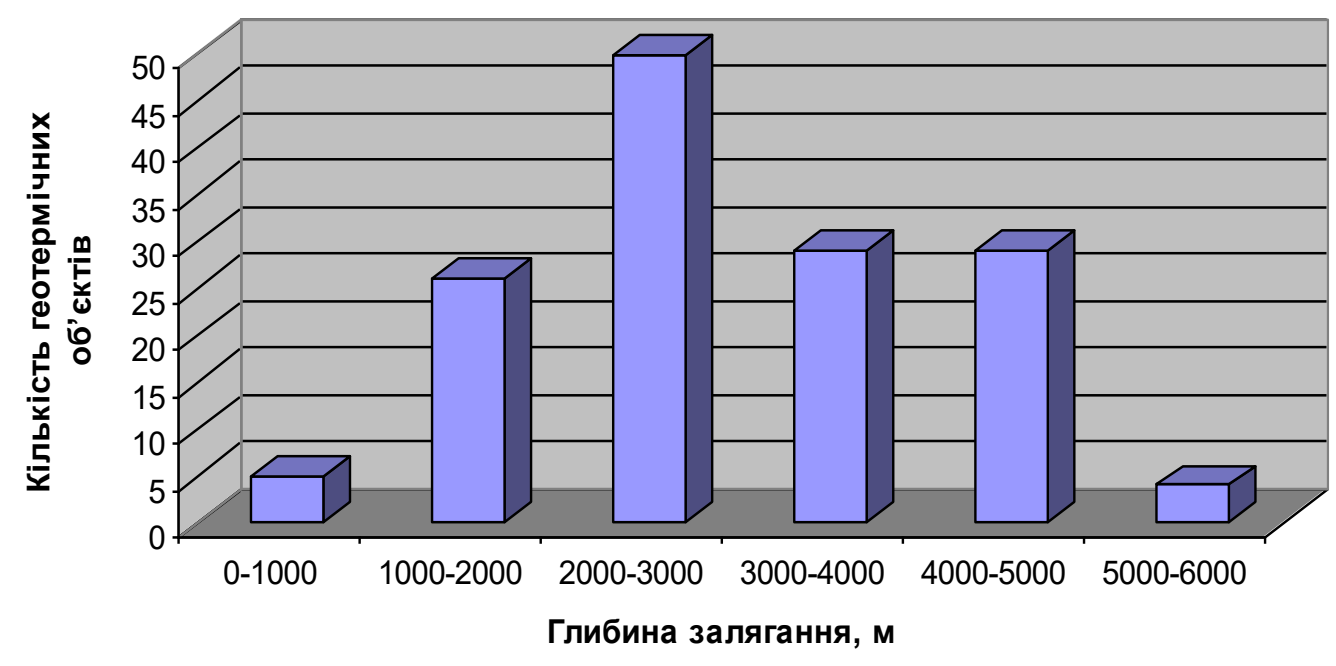

Рис. 9. Розподіл глибин залягання геотермальних об'єктів Дніпровсько-Донецького артезіанського басейну.

Fig. 9. Aquifer depth distributions in geothermal the objects of the Dnieper-Donetsk artesian basin. 


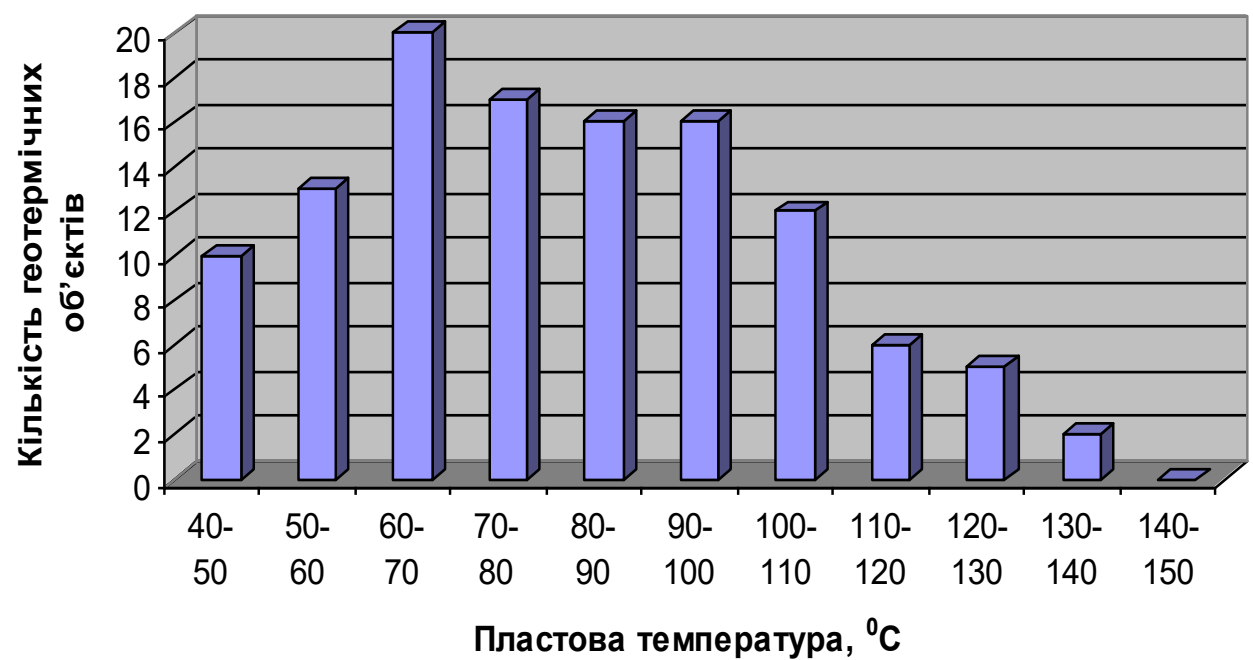

Рис. 10. Розподіл пластових температур у геотермальних об’єктах Дніпровсько-Донецького артезіанського басейну.

Fig. 10. Aquifer reservoir temperatures distribution in the geothermal objects of the Dnieper-Donetsk artesian basin.

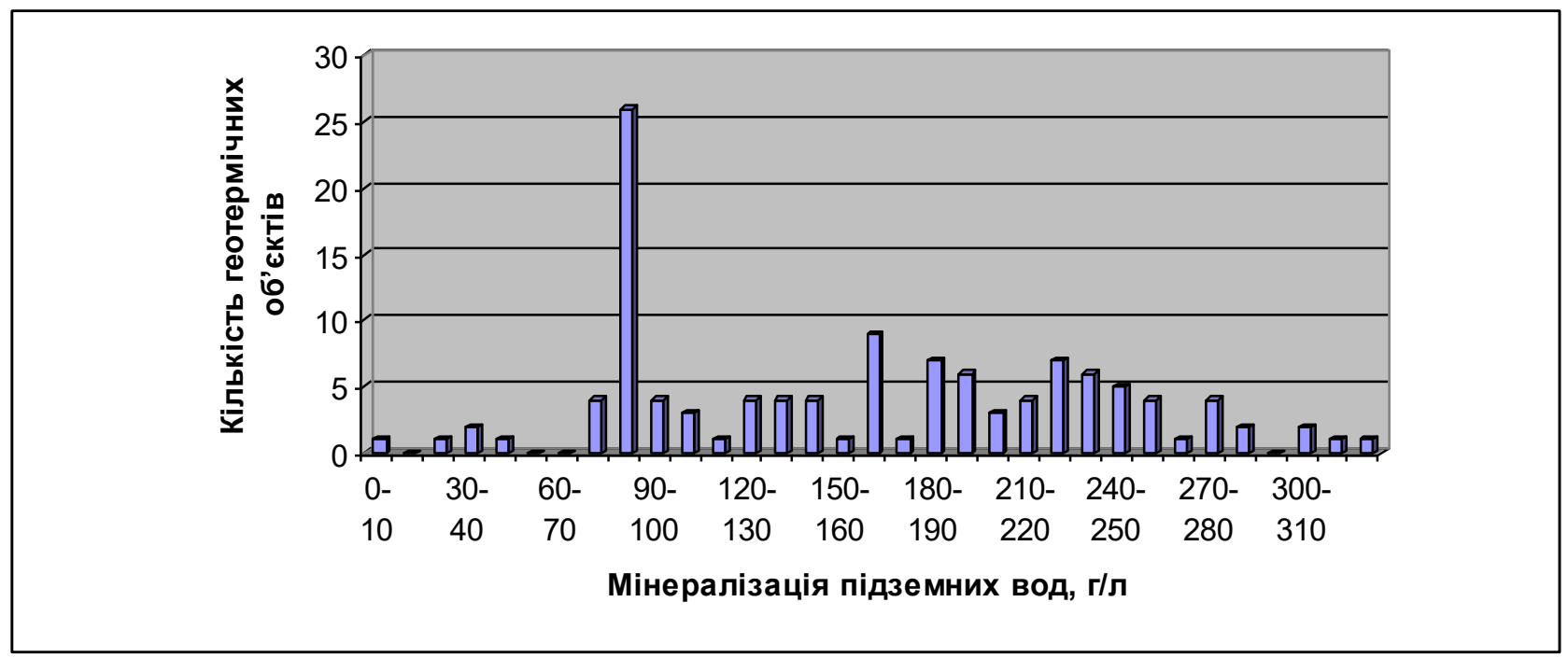

Рис. 11. Розподіл мінералізації підземних вод у геотермальних об'сктах Дніпровсько-Донецького артезіанського басейну.

Fig. 11. Underground mineralization distribution in the geothermal objects of the Dnieper-Donetsk artesian basin.

Причорноморський артезіанський басейн. залягання і пластові температури (рис. 10 i На території цієї структури розташовано 59 гео- рис. 11). Середній геотермічний градієнт складає термальних об'єктів Херсонської області, 3 об'єкта Одеської області та 25 -АР Крим.

Основною областю живлення водоносних горизонтів є південний схил Українського кристалічного масиву. Поверхня кристалічного фундаменту нахилена 3 півночі на південь від Українського щита в сторону Чорного моря. В районі Одеської та Херсонської областей фундамент занурюється на глибину до 2000 м. Тому геотермальні об’єкти мають відносно невелику глибину $2,5{ }^{\circ} \mathrm{C} / 100$ м. Найбільш прогрітою $є$ південна частина Херсонської області.

Основні термоводоносні горизонти приурочені до осадових утворень крейдяного, палеогенового і неогенового віку, представлені пісковиками, вапняками і аргілітами, тобто продуктивні горизонти мають переважно пластовий тип. Горизонти високо напірні, статичні рівні встановлюються на глибинах \pm 50 м від гирла свердловин. 


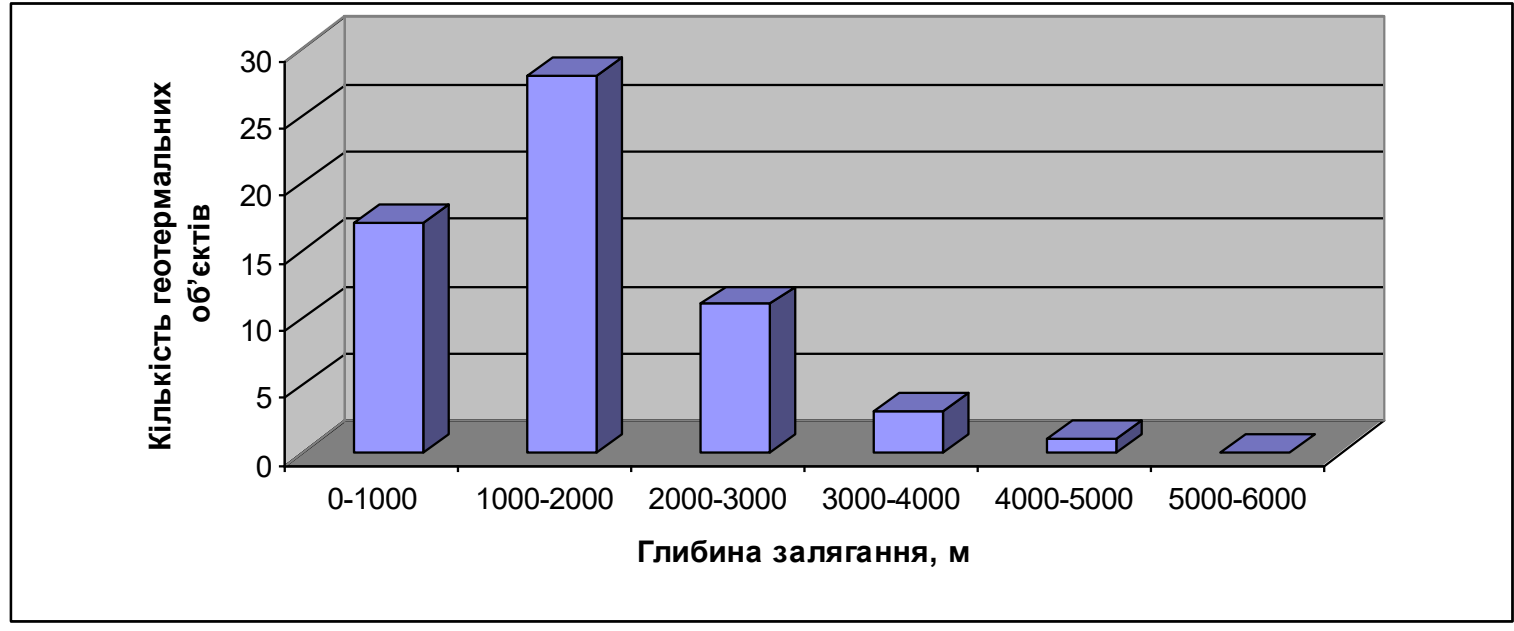

Рис. 12. Розподіл глибин залягання геотермальних об’єктів Причорноморського артезіанського басейну.

Fig. 12. Aquifer depth distributions in the geothermal objects of the Black Sea artesian basin.

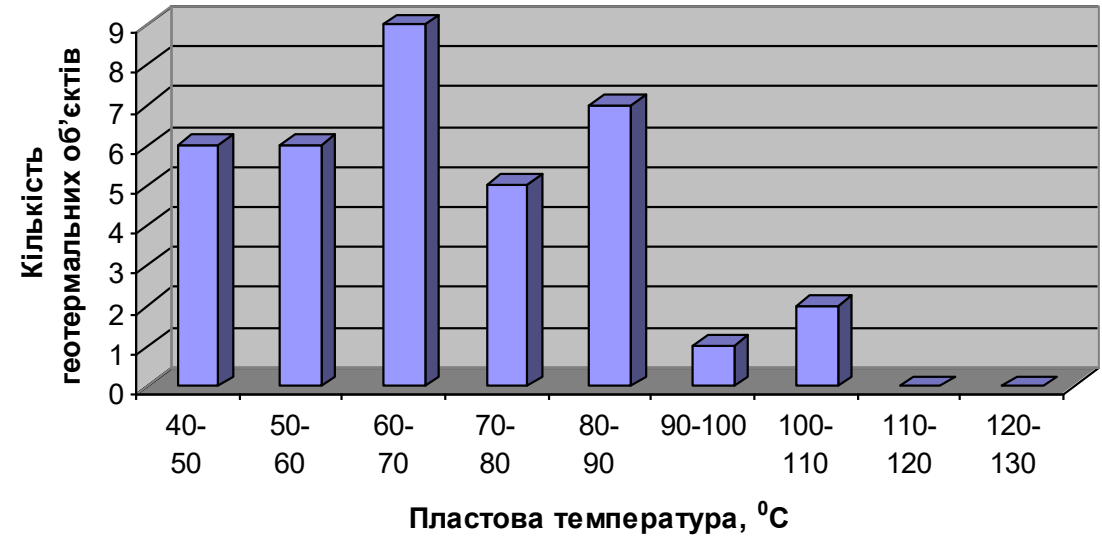

Рис. 13. Розподіл пластових температур у геотермальних об’єктах Причорноморського артезіанського басейну.

Fig. 13. Aquifer reservoir temperatures distribution in the geothermal objects of the Black Sea artesian basin.

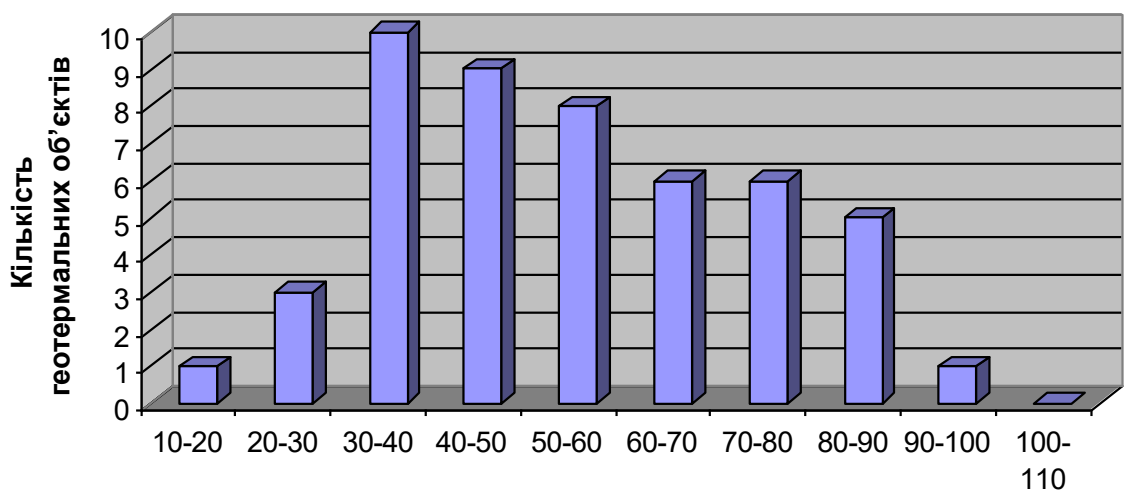

Мінералізація підземних вод, г/л

Рис. 14. Розподіл мінералізації підземних вод у геотермальних об'сктах Причорноморського артезіанського басейну.

Fig. 14. Underground mineralization distribution in the geothermal objects of the the Black Sea artesian basin. 
Висновки. 1. На основі матеріалів «Державного інформаційного геологічного фонду України» створено електрону базу геотермальних об'єктів України. База даних налічує 652 геотермальних об'єкта і охоплює $54 \%$ існуючих родовищ вуглеводнів.

2. Визначено, що до основних гідрогеологічних і геотермічних характеристик геотермального об' єкту належать: глибина залягання, літологія і склад порід, геологічний вік порід, товщина продуктивного горизонту, пластова температура і пластовий тиск, дебіт свердловини, зниження рівня води у водоносному горизонті під час випробування, мінералізація, газовий склад i вміст природного газу у підземних водах.

3. Побудовано діаграми розподілу пластових температур, глибин залягання і мінералізації підземних вод в геотермальних об'єктах бази даних

4. Аналіз геологічних і геотермічних характеристик об'єктів бази даних показав, що умови формування геотермальних родовищ в першу чергу залежать від теплового фону земних надр, але на процеси формування родовищ істотно впливає глибина залягання кристалічного фундаменту, літологічний склад порід і розташування області живлення та розвантаження термоводоносних горизонтів.

1. Барило А.А. Особливості класифікації геотермальних ресурсів. Відновлювана енергетика. 2009. № 3(18). С. 56-59.

2. Барило А.А., Морозов Ю.П. Оцінка енергетичного потенціалу окремих геотермальних родовищ України. Відновлювана енергетика. 2017. № 1(48). С. 72-79.

3. Морозов Ю.П., Барило А.А. Первоочередные объекты практического использования геотермальных месторождений Украины. Альтернативная энергетика и экология. Саров. 2014. № 2(142). С. 112-116.

4. Морозов Ю.П. Добыча геотермальных ресурсов и аккумулирование теплоты в подземных горизонтах. К. Наукова думка. 2017. 197 с.

5. Іванюта М.М. Атлас нафтових і газових родовищ України (в 6 т.). Львів. Вид-во «Центр Свропи». 1998. Т.1-3. 1421 c., Т.4-5. 707 с., Т.6. 224 c.

6. Галецький Л.С. Атлас геологія і корисні копалини України. К. НАНУ. Мін. екології та природних ресурсів України. 2001. 168 с.

7. Соболевский Э.Э. Оценка запасов термальних вод УССР. Звіт центральної комплексної тематичної експедиції. кн. 1-3. 1979. Кн. 1.189 с.

8. Колодій В.В., Паньків Р.П. Гідрогеологія нафтових і газових родовищ Карпатської нафтогазоносної провінції (в межах України). Звіт Західної НГРЕ. 2005. кн.1-5. Кн. 1. 176 с.
9. Гордієнко В.В., Гордієнко I.В., Завгородня О.В., Усенко О.В. Теплове поле території України. К. Знання України. 2002. $168 \mathrm{c.}$

10. Гордієнко В.В., Гордієнко I.В., Завгородня О.В. та інш. Геотермический атлас Украины. К. ІГФ НАНУ. 2004. 59 с.

\section{REFERENCES}

1. Barylo A.A. Osoblyvosti klasyfikatsii heotermalnykh resursiv. [Features of classification of geothermal resources]. Vidnovluvana energetika. 2009. No. 3(18). Pp. 56-59. [in Ukrainian].

2. Barylo A.A., Morozov Yu.P. Otsinka enerhetychnoho potentsialu okremykh heotermalnykh rodovyshch Ukrainy. [Assessment of energy potential of individual geothermal deposits in Ukraine]. Vidnovluvana energetika. 2017. No. 1(48). Pp. 72-79. [in Ukrainian].

3. Morozov Yu.P., Barilo A.A. Pervoocherednyie obektyi prakticheskogo ispolzovaniya geotermalnyih mestorozhdeniy Ukrainyi. [Priority objects of practical use of geothermal deposits of Ukraine]. Alternativnaya energetika i ekologiya. Sarov. 2014. No. 2. Pp. 112-116. [in Russian].

4. Morozov Yu.P. Dobyicha geotermalnyih resursov i akkumulirovanie teplotyi $\mathrm{v}$ podzemnyih gorizontah. [Geothermal mining and heat storage in underground horizons]. Naukova Dumka. Kyiv. 2017. 197 p. [in Russian].

5. Ivaniuta M.M. Atlas naftovykh i hazovykh rodovyshch Ukrainy (v 6 t.). [Atlas of Oil and Gas Deposits of Ukraine (6 v.)]. Tsentr Yevropy. Lviv. 1998. Vol. 1-3. 1421 p. Vol. 4-5. 707 p. Vol. 6. 224 p. [in Ukrainian].

6. Haletskyi L.S. Atlas heolohiia i korysni kopalyny Ukrainy. [Atlas Geology and Minerals of Ukraine]. Minysterstvo ekolohii ta pryrodnykh resursiv Ukrainy. Kyiv. 2001. 168 p. [in Ukrainian].

7. Sobolevskyi Ye.Ye. Otsenka zapasov termalnykh vod USSR. [Estimation of thermal water reserves of the USSR].Report of the Central Comprehensive Thematic Expedition. book 1-3. 1979. book 1. 189 p. [in Russian].

8. Kolodii V.V., Pankiv R.P. Hidroheolohiia naftovykh i hazovykh rodovyshch Karpatskoi naftohazonosnoi provintsii (v mezhakh Ukrainy). [Hydrogeology of oil and gas fields of Carpathian oil and gas province (within Ukraine)]. Zvit Zakhidnoi NHRE [Western Oil and Gas Expedition Report]. book 1-5. 2005. book 1. 176 p. [in Ukrainian].

9. Hordiienko V.V., Hordiienko I.V., Zavhorodnia O.V., Usenko O.V. Teplove pole terytorii Ukrainy. [Thermal field of the territory of Ukraine]. Znannia Ukrainy. K. 2002. 168 p. [in Ukrainian].

10. Hordiienko V.V., Hordiienko I.V., Zavhorodnia O.V. and others Geotermicheskiy atlas Ukrainyi. [Geothermal Atlas of Ukraine]. K. IHF NANU. [Institute of Geophysics]. 2004. 59 p. [in Russian].

\section{АНАЛИЗ ГИДРОГЕОЛОГИЧЕСКИХ И ГЕОТЕРМИЧЕСКИХ ХАРАКТЕРИСТИК ГЕОТЕРМАЛЬНЫХ ОБЬЕКТОВ УКРАИНЫ}

\section{А.А. Барило}

Институт возобновляемой энергетики НАН Украины, 02094, ул. Гната Хоткевича 20A, г. Киев, Украина. 
На основе материалов «Государственного информационного геологического фонда Украиньу» создана база данных геотермальных объектов, в которую вошло 652 объекта, которые охватывают 12 административных областей Украины и около $54 \%$ существующих месторождений углеводородов. Основными геотермическими и гидрогеологическими характеристиками объектов базы данных являются: глубина залегания, литология и состав пород, геологический возраст пород, толщина продуктивного горизонта, пластовая температура и пластовое давление, дебит скважины, понижение уровня воды в водоносном горизонте при испытании, минерализация, газовый состав и содержание природного газа в подземных водах.

Анализ гидрогеологических и геотермических характеристик геотермальных объектов выполнен на основе структурно-гидрогеологического приниипа, то есть все объекты рассматривались относительно крупных гидрогеологических структур с едиными границами и условиями формирования месторождений подземных вод, а именно: Закарпатский внутренний прогиб, Прикарпатский предгорный про- гиб, Днепровско-Донеикий артезианский бассейн и Причерноморский артезианский бассейн. Для каждой структурь построены диаграммы распределения пластовых температур, глубин залегания и минерализачии подземных вод в геотермальных объектах базы данных.

Анализ показал, что условия формирования геотермальных месторождений в первую очередь зависят от теплового фона земных недр, но на прочессы формирования месторождений очень существенное влияние оказывают: глубина залегания кристаллического фундамента, расположение областей питания и разгрузки термоводоносных горизонтов, глубина современного водообмена, литологический состав водовмещяаюиих пород.

База данных геотермальных объектов Украины может быть использована при выборе первоочередных для освоения геотермальных объектов, а также для стратегического планирования геотермальной отрасли в целом. Библ. 10, рис. 14.

Ключевые слова: геотермальный объект, электронная база данных, геотермическая характеристика, гидрогеологическая характеристика, диаграмма распределения

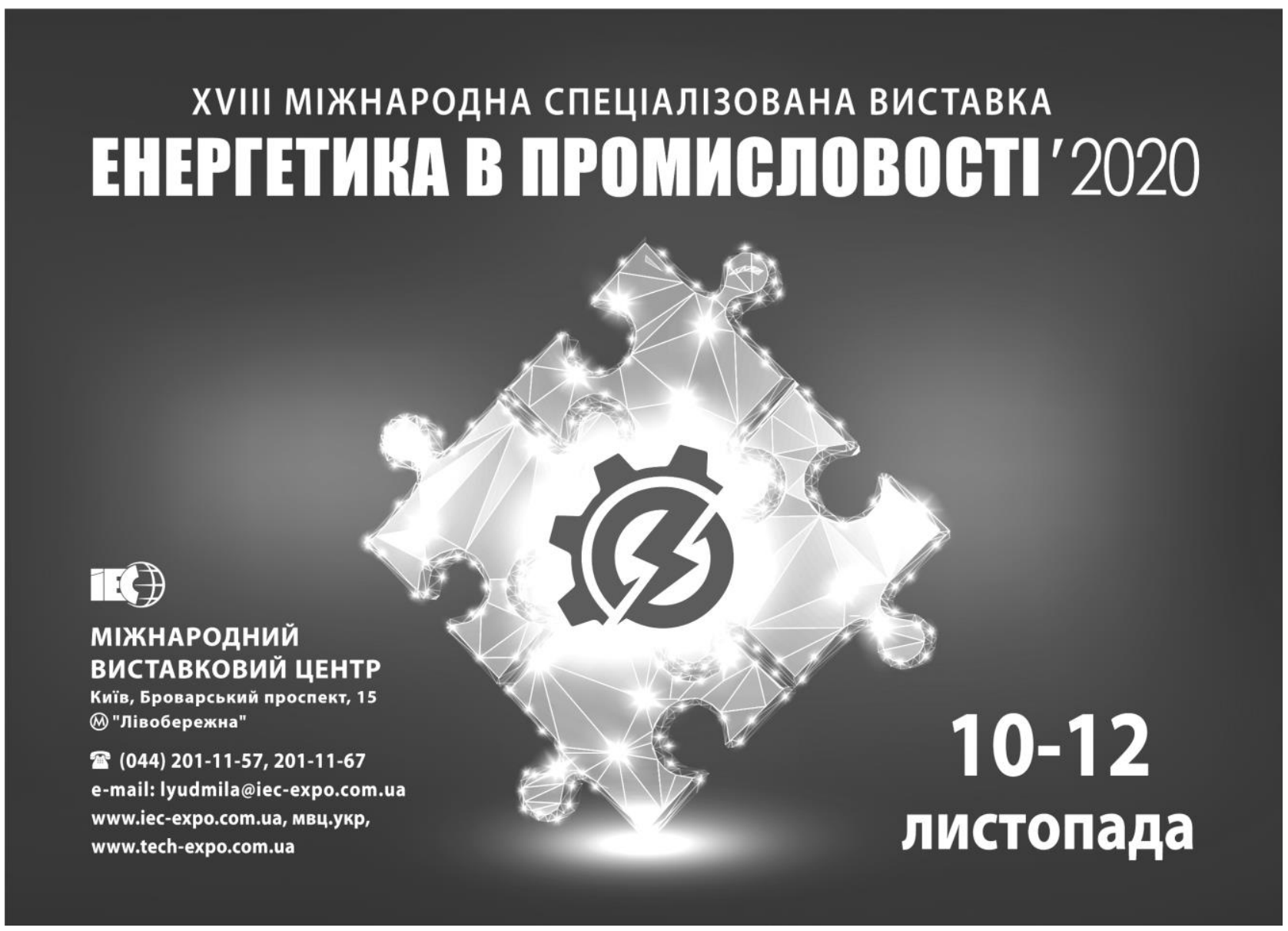

